\title{
Data report: consolidation state and stress ratio of clay-rich sediments from Site U1320'
}

\author{
Maria Ask ${ }^{2}$
}

\section{Chapter contents}

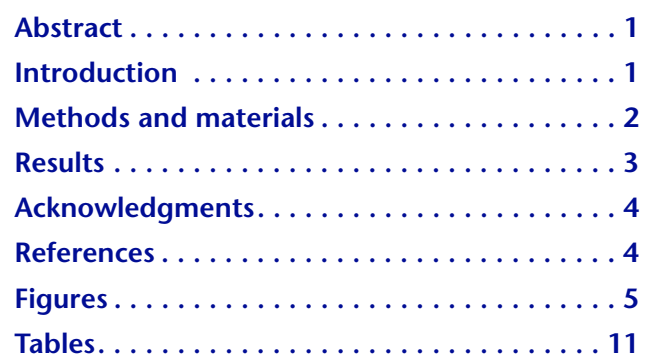

${ }^{1}$ Ask, M., 2009. Data report: consolidation state and stress ratio of clay-rich sediments from Site U1320. In Flemings, P.B., Behrmann, J.H., John, C.M., and the Expedition 308 Scientists, Proc. IODP, 308: College Station, TX (Integrated Ocean Drilling Program Management International, Inc.). doi:10.2204/iodp.proc.308.207.2009

${ }^{2}$ Department of Civil and Environmental Engineering, Division of Mining and Geotechnical Engineering, Luleå University of Technology, SE97187 Luleå, Sweden.

Maria.Ask@Itu.se

\begin{abstract}
Overpressure and fluid flow processes in the deepwater Gulf of Mexico were investigated during Expedition 308 of the Integrated Ocean Drilling Program.

This data report presents the results from a reconsolidation test that was carried out on a clay-rich sample from the base of BrazosTrinity Basin IV, at $276.40 \mathrm{~m}$ below seafloor. The sample was subjected to a stress path of uniaxial strain ( $K_{0}$ reconsolidation), and the test was conducted in an advanced triaxial cell under drained conditions. Posttest investigation revealed that the sample was disturbed by drilling. The results should be interpreted with care.

The sample was loaded to a total effective vertical stress, $\sigma_{v}{ }^{\prime}$, of 24 $\mathrm{MPa}$, corresponding to effective horizontal stress, $\sigma_{\mathrm{h}}{ }^{\prime}$, of $>16 \mathrm{MPa}$ and vertical strain, $\varepsilon_{v}$, of $16 \%$. The results propose an effective vertical yield stress of $2.03 \mathrm{MPa}$, which suggests a maximum pore fluid pressure in excess of hydrostatic water pressure of $0.24 \mathrm{MPa}$. Furthermore, the ratio between effective horizontal and vertical stresses is rather constant, $\sim 0.7$, even at high stress magnitudes.
\end{abstract}

\section{Introduction}

A central objective in structural geology is to interpret the deformation histories of geological bodies and the stress paths responsible for those histories. Such stress and strain histories are important for a proper understanding of mechanical behavior, porefluid pressure, and fluid flow in the upper crust. Knowledge of the stress evolution is vitally important in understanding natural phenomena (e.g., slope failures).

The understanding of the nature of stress and stress paths that produce deformation has advanced remarkably over the past decades, both from laboratory experiments and in situ stress measurements (e.g., Jones, 1994; Karig and Morgan, 1994; Dugan and Flemings, 2000; Karig and Ask, 2003).

Laboratory deformation experiments on sediments are inexpensive and easy to perform compared to in situ measurements. Laboratory experiments also enable uniform sediment to be subjected to varying stress and strain conditions to better isolate functional dependencies. However, some limitations are

- A much faster strain rate in the laboratory than in nature, 
- Problems with mimicking diagenetic processes in the laboratory, and

- The ability to apply only simple stress paths in laboratory experiments (Karig and Morgan, 1994).

The last limitation can to some extent be mitigated by conducting multiple tests on samples with different orientation and stress paths.

Passive continental margins are examples of tectonically quiescent areas, for which the anticipated stress path is assumed to approximate uniaxial strain, as caused by gravitational loading from deposition. The U.S. Gulf Coast passive margin is suitable for studying properties and processes related to sediment consolidation and fluid flow in sediments with varying pore-fluid pressure (e.g., Flemings et al., 2005).

Based on data collected by the petroleum industry along the U.S. Gulf Coast, Breckels and van Eekelen (1982) investigated the $K_{0}$ stress ratio and the variation of pore-fluid pressure. The $K_{0}$ stress ratio is the ratio between effective horizontal and vertical stress. It is also referred to as "earth pressure at rest." Low $K_{0}$ values indicate brittle behavior; high $K_{0}$ values indicate ductile behavior. Breckels and van Eekelen (1982) proposed that the stress ratio increases from $\leq 0.3$ near the surface to 1.0 near $6 \mathrm{~km}$ depth. Karig and Morgan (1994) argued against their interpretation and proposed a higher $K_{0}$ stress ratio of $\sim 0.5$ for sections with hydrostatic pore-fluid pressure. The more recent Pathfinder Drilling Program consisted of both in situ stress measurements and laboratory deformation tests (e.g., Finkbeiner et al., 2001; Stump and Flemings, 2002). The tests on two lightly cemented mudstone samples by Stump and Flemings (2002) showed that the $K_{0}$ stress ratio changes when the samples yield, from preyield values of $0.52-0.63$ to postyield values of $0.85-0.86$. Further experiments are clearly needed to investigate how the principal stress magnitudes increase with depth in this setting.

The objective for this study is to explore and understand the basic consolidation processes occurring in shallow sedimentary rock formations by

- Measuring how the stress ratio of the effective principal stress magnitudes develop in elastic and plastic-elastic reconsolidation and

- Determining in situ and laboratory relationships between in situ effective stress state and pore volume (e.g., porosity and void ratio).

Among other objectives, these data can be used in pore pressure prediction from drilling and log data.

\section{Methods and materials}

\section{Samples}

Whole-round Sample 308-U1320A-31X-1, 120-150 $\mathrm{cm}$, was collected from 276.4-276.7 meters below seafloor (mbsf), from the base of Brazos-Trinity Basin IV where sediments were assumed to have been normally consolidated (i.e., the internal pore pressure has been dissipated so that hydrostatic pressure has been maintained during deposition). Cylindrical Sample 1320-31-1 was cored with a water-lubricated rotary coring tube from the whole-round core sample. The sample had a diameter of $21.23 \mathrm{~mm}$ and a height of $55.27 \mathrm{~mm}$ (i.e., 2.5 times the diameter). Initial bulk density was calculated from measurements of the wet volume and wet weight of the sample, and porosity was derived from this bulk density value and shipboard values of grain and water densities. The shore-based values of bulk density and porosity were $1.93 \mathrm{~g} / \mathrm{cm}^{3}$ and $48 \%$, respectively. Hence, shore-based bulk density is slightly lower and porosity is slightly higher than those of adjacent shipboard values $\left(2.02 \mathrm{~g} / \mathrm{cm}^{3}\right.$ and $43 \%$, respectively).

Sample $1320-31-1$ is a gray clay with darker vaguely subhorizontal and probably bioturbated layers. It was collected from Unit V, which is dominated by hemipelagic generally bioturbated clay with rare silt lamina often containing fragments of foraminifers (Flemings et al., 2005). Coarser grains may be derived from river plumes and/or very low density turbidity currents.

Visual inspection of the sample revealed no drilling disturbance, so it was assumed that the sample was undisturbed. However, posttest investigation of the remaining whole-round sample revealed the presence of drill biscuits (Fig. F1).

\section{Testing setup and procedure}

The experiment was carried out with the test equipment of Karig (1996). This laboratory was previously housed at Cornell University, Ithaca (USA), but it is now located at Luleå University of Technology.

The equipment consists of a triaxial cell mounted in a computer-controlled servo-hydraulic INSTRON 1324 load frame (cf. figure 6 of Morgan and Ask, 2004). Figure F2 shows the instrumentation of the test sample within the triaxial cell. Horizontal strains are measured by an array of eight linear variable differential transformers (LVDTs) across four diameters at the midheight of the sample. One pair of LVDTs measures the vertical strain over the middle half of 
the sample, and one LVDT mounted outside the triaxial cell measures the external vertical strain. A latex jacket isolates the sample from the silicon oil confining fluid. Testing was conducted under drained conditions, with the pore fluid allowed to drain in and out through both ends of the sample. The slow loading rate and the double drainage are assumed to result in fully drained conditions within the sample. A total of 11 digitized channels monitored loading and dimensional data, which were saved every 15 or 30 min during testing, providing detailed information about sample deformation and strength.

The testing sequence included a preconsolidation phase, which lasted for $39 \mathrm{~h}$, at constant vertical and horizontal stresses of $\sim 1.7 \mathrm{MPa}$ and a back-pore pressure of $1.0 \mathrm{MPa}$. Each sample was first brought to a uniform isotropic stress state to ensure that all remaining gases in the system were in solution during the test phase. The reconsolidation phase began immediately after the preconsolidation phase and followed a $K_{0}$ reconsolidation computer-controlled stress path: vertical stress was increased at a constant rate $(11.5 \mathrm{~Pa} / \mathrm{s})$ while the horizontal stress (confining pressure) was adjusted by computer control to maintain a constant cross-sectional area of the sample. At the outset of the $K_{0}$ reconsolidation test, the sudden change in stress state from initially isotropic stresses to uniaxial strain led to boundary effects. System compliance effects and closure of microcracks also affected the response during the initial phase of the $K_{0}$ reconsolidation tests.

\section{$K_{0}$ stress ratio, yield stress, and pore fluid pressure}

The stress ratio, $K_{0}$, is defined as the ratio between the effective horizontal and vertical stresses $\left(\sigma_{h}{ }^{\prime}\right.$ and $\sigma_{v}{ }^{\prime}$, respectively) (Table T1), which maintain the condition of uniaxial strain. $K_{0}$ of elastic and plastic conditions are obtained by linearly fitting $\sigma_{\mathrm{v}}{ }^{\prime}$ and $\sigma_{\mathrm{h}}{ }^{\prime}$ data pre- and postyield stress. $K_{0}$ may also be calculated from plots of $\sigma_{\mathrm{m}}{ }^{\prime}$ versus $\Delta \sigma$ (Table T1).

The effective vertical yield stress, $\sigma_{y}{ }^{\prime}$, marks the transition from elastic to plastic elastic deformation along the $K_{0}$ reconsolidation stress path. For uncemented sediments, the yield stress corresponds to the preconsolidation pressure. There are several methods for determining the preconsolidation pressure (e.g., Casagrande, 1936; Becker et al., 1987; Wang and Frost, 2004). Because it is difficult to obtain the true preconsolidation pressure, it is hard to evaluate the relative merits of the different methods. In this paper, I have adopted the method of Karig (1993): I have used various relationships among the collected data (e.g., $\sigma_{\mathrm{h}}{ }^{\prime}$ versus $\sigma_{\mathrm{v}}{ }^{\prime}, \Delta \sigma$ versus $\sigma_{\mathrm{m}}{ }^{\prime}$, and $\sigma_{v}{ }^{\prime}$ versus $\varepsilon_{v}$ ) and picked the yield stress at the point where the rate of deviation from the elastic slope began to change rapidly.

The effective vertical yield stress, $\sigma_{y}^{\prime}$, may be compared with the calculated in situ effective vertical stress for hydrostatic water pressure, $\sigma_{\mathrm{vh}}{ }^{\prime}$ (e.g., Karig, 1996). The difference between the two values is a measure of the maximum pore fluid pressure in excess of hydrostatic water pressure, $P^{\star \max }$ (Table T1). The magnitude of the importance of the overpressure is often shown by the overpressure ratio, $\lambda *$ (e.g., Long et al.). The ratio between $P^{\star \max }$ and $\sigma_{\mathrm{vh}}{ }^{\prime}$ gives a maximum value of $\lambda *$ (Table T1).

\section{Results}

Table T1 lists symbols commonly used in the text. Morgan and Ask (2004) presents the background of these values in more detail. The preconsolidation phase was longer than normal, $39 \mathrm{~h}$, because an external pore water leak was found. The source of the leak could not be identified, and the preconsolidation phase was terminated once it was clear that remaining parameters were stable. The first test results from the preconsolidation phase are listed in Table T2, and the full results can be found in Microsoft Excel format as PRECONSOL.XLS in STRESS in "Supplementary material."

The reconsolidation phase was run for $>645 \mathrm{~h}$ (Fig. F3). The test unexpectedly shut down four times, but test conditions were reestablished reasonably well (at $100 \mathrm{~h}$, there was an increase in cross-sectional area; at 100 and $140 \mathrm{~h}$, small shifts in axial strain).

Sample 1320-31-1 was loaded to a total effective vertical stress, $\sigma_{v}{ }^{\prime}$, of $24 \mathrm{MPa}$, corresponding to effective horizontal stress, $\sigma_{\mathrm{h}}{ }^{\prime}$, of $>16 \mathrm{MPa}$ and vertical strain, $\varepsilon_{v}$, of $16 \%$ (Fig. F3). Initial inspection of samples and analyses of test results proposed that Sample 132031-1 was uncemented and undisturbed. However, posttest computer tomography scans and paleomagnetic studies (anisotropy of magnetic susceptibility) reveal that the sample indeed is disturbed and comprises three drill biscuits (Fig. F1). Because of the short spacing between the three drill biscuits and because the sample was collected in a basin in which sediments are assumed to be transversely isotropic, the results may still be of some interest, especially at greater stresses, at least for stress-stress plots.

Table T3 shows the results from the first hours of testing during the $K_{0}$ reconsolidation phase, and Figure $\mathbf{F} 4$ shows how the stress ratio and vertical strain vary with increasing stress during the entire test. The complete data set from the test results is available in 
Microsoft Excel format as RECONSOL.XLS in STRESS in "Supplementary material." The plot of $\sigma_{v}{ }^{\prime}$ versus $\varepsilon_{v}$ best shows the initial nonlinear deformation when microcracks are closed and the transition from elastic to plastic deformation. In comparison, the stressstress plots reveal more subtle changes. The preconsolidation stress is inferred to be $2.03 \mathrm{MPa}$ based on the change in slope in the stress-strain curve shown in Figure F4C. Based on shipboard data, the in situ effective vertical stress for hydrostatic water pressure, $\sigma_{\mathrm{vh}}{ }^{\prime}$, is calculated to be $2.27 \mathrm{MPa}$, which results in a maximum pore fluid pressure in excess of hydrostatic water pressure, $P^{\star \max }$, of $0.24 \mathrm{MPa}$. This corresponds to a $\lambda *$ of 0.11 . The small difference between $\sigma_{\mathrm{vh}}{ }^{\prime}$ and $\sigma_{\mathrm{y}}{ }^{\prime}$ is probably insignificant, especially when comparing the results with studies that use other methods to determine $\sigma_{y}^{\prime}$ (or preconsolidation pressure). The results propose that the sample is normally consolidated. There is a subtle change in stress ratio across $\sigma_{y}{ }^{\prime}$, and the stress ratio, $K_{0}$, changes from 0.70 before yield to 0.69 after yield for the entire data set. A more detailed inspection of the data reveal minor shifts in the stress magnitudes when the test unexpectedly shut down four times: postyield $K_{0}$ values range from 0.65 to 0.68 within the continuous test sequences (Fig. F4A). The overall trend reveals that the stress ratio is constant up to an effective vertical stress of nearly $25 \mathrm{MPa}$.

\section{Acknowledgments}

This research used samples and data provided by the Integrated Ocean Drilling Program (IODP), collected during IODP Expedition 308. Funding was provided by a start-up grant from the Swedish IODP committee of the Swedish Research Council. Dr. Lena Antii and her co-workers at Luleå University of Technology, Skellefteå, are thanked for helping me with CT scans, and Dr. Yuzuru Yamamoto at the Geological Survey of Japan is thanked for paleomagnetic investigations. Dr. Demian Saffer at The Pennsylvania State University and Prof. Peter Flemings at The University of Texas at Austin are thanked for their reviews that improved the manuscript.

\section{References}

Becker, D.E., Crooks, J.H.A., Been, K., and Jeffries, M.G., 1987. Work as a criterion for determining in situ and yield stresses in clays. Can. Geotech. J., 24(4):549-564. doi:10.1139/t87-070

Breckels, I.M., and van Eekelen, H.A.M., 1982. Relationship between horizontal stress and depth in sedimentary basins. JPT, J. Pet. Technol., 34(9):2191-2199. doi:10.2118/10336-PA
Casagrande, A., 1936. The determination of pre-consolidation load and its practical significance. In Casagrande, A., Rutledge, P.C., and Watson, J.D. (Eds.), Proc. 1st Int. Conf. Soil Mech. Found. Eng., Am. Soc. Civ. Eng., 3:60-64.

Dugan, B., and Flemings, P.B., 2000. Overpressure and fluid flow in the New Jersey continental slope: implications for slope failure and cold seeps. Science, 289(5477):288-291. doi:10.1126/science.289.5477.288

Finkbeiner, T., Zoback, M., Flemings, P., and Stump, B., 2001. Stress, pore pressure, and dynamically constrained hydrocarbon columns in the south Eugene Island 330 field, northern Gulf of Mexico. AAPG Bull., 85(6):1007-1031.

Flemings, P.B., Behrmann, I., Davies, T., John, C., and the Expedition 308 Project Team, 2005. Gulf of Mexico hydrogeology-overpressure and fluid flow processes in the deepwater Gulf of Mexico: slope stability, seeps, and shallow-water flow. IODP Sci. Prosp., 308. doi:10.2204/ iodp.sp.308.2005

Jones, M., 1994. Mechanical principles of sediment deformation. In Maltman, A. (Ed.), The Geological Deformation of Sediments: London (Chapman and Hall), 37-71.

Karig, D.E., 1983. Reconsolidation tests and sonic velocity measurements of clay-rich sediments from the Nankai Trough. In Hill, I.A., Taira, A., Firth, J.V., et al., Proc. ODP, Sci. Results, 131: College Station, TX (Ocean Drilling Program), 247-260. doi:10.2973/odp.proc.sr.131.127.1993

Karig, D.E., 1996. Uniaxial reconsolidation tests on porous sediments: mudstones from Site 897. In Whitmarsh, R.B., Sawyer, D.S., Klaus, A., and Masson, D.G. (Eds.), Proc. ODP, Sci. Results, 149: College Station, TX (Ocean Drilling Program), 363-373. doi:10.2973/odp.proc.sr.149.234.1996

Karig, D.E., and Ask, M.V.S., 2003. Geological perspectives on consolidation of clay-rich marine sediments. J. Geophys. Res., [Solid Earth], 108(B4):2197. doi:10.1029/ 2001JB000652

Karig, D.E., and Morgan, J.K., 1994. Tectonic deformation: stress paths and strain histories. In Maltman, A. (Ed.), The Geological Deformation of Sediments: London (Chapman and Hall), 167-204.

Morgan, J.K., and Ask, M.V.S., 2004. Consolidation state and strength of underthrust sediments and evolution of the décollement at the Nankai accretionary margin: results of uniaxial reconsolidation experiments. J. Geophys. Res., [Solid Earth], 109(B3):B03102. doi:10.1029/ 2002JB002335

Stump. B.B., and Flemings, P.B., 2002. Consolidation state, permeability, and stress ratio as determined from uniaxial strain experiments on mudstone samples from the Eugene Island 330 area, offshore Louisiana. In Huffman, A.R., and Bowers, G.L. (Eds.), Pressure Regimes in Sedimentary Basins and their Prediction. AAPG Mem., 76:131-144.

Wang, L.B., and Frost, J.D., 2004. Dissipated strain energy method for determining preconsolidation pressure. Can. Geotechn. J., 41(4):760-768.

Initial receipt: 5 March 2008

Acceptance: 12 January 2009

Publication: 6 May 2009

MS 308-207 
Figure F1. Computed tomography scan of whole-round Sample 308-U1320A-31X-4, 120-126 cm (276.40-276.46 mbsf). Sample 1320-31-1 is cut immediately to the right of the scan. Black arrows $=$ three drill biscuits.

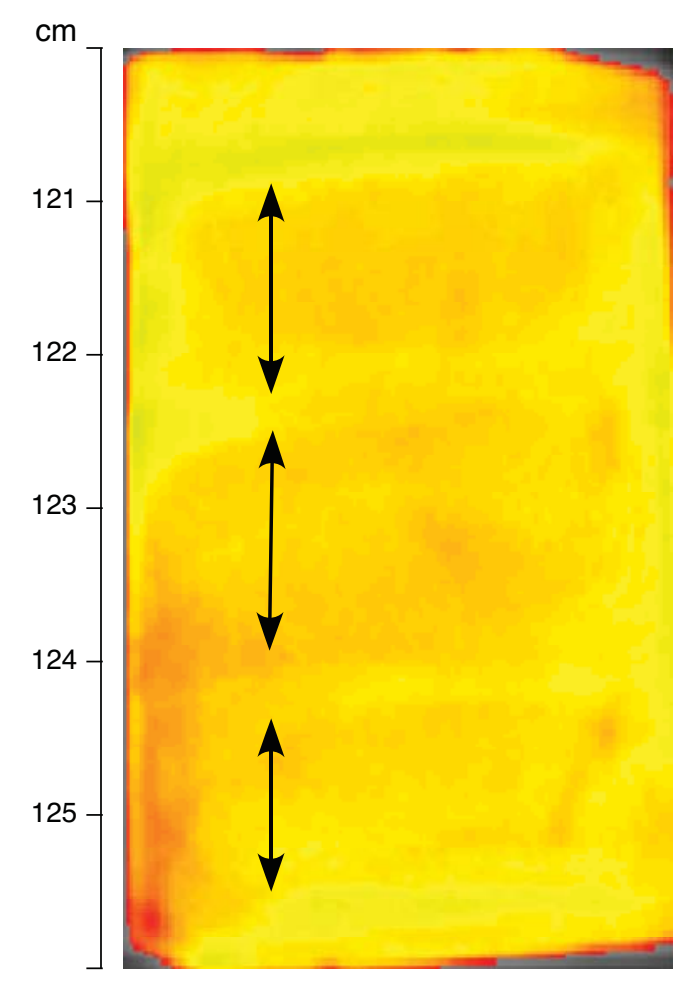


Figure F2. Photograph of experimental setup of Sample 1320-31-1. Sample is mounted within a latex jacket (1). Horizontal strains are measured across four pairs of linear variable transducers (LVDTs) in a ring at sample midsection (2). Vertical strains are measured by one pair of LVDTs attached to rings spanning the central section of the sample (3). Differential stress is measured by a load cell (4) mounted above the upper platen (5). Pore fluid can be drained from either or both ends of the sample (6). Fixture used to stabilize the experimental setup during mounting of the test, removed during testing (7).

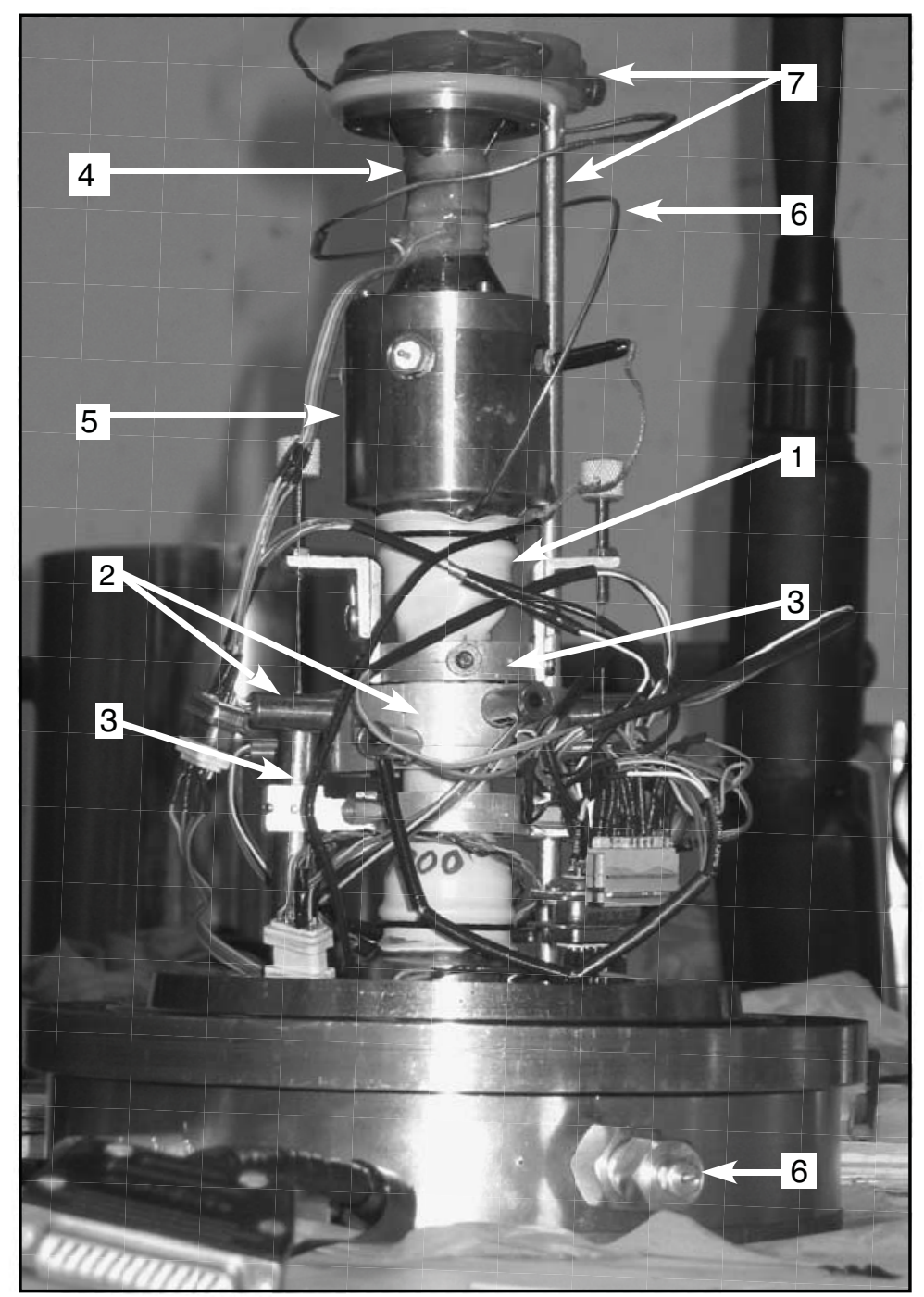


Figure F3. Plot of results from the reconsolidation phase. Effective vertical $\left(\sigma_{v}{ }^{\prime}\right)$ and horizontal $\left(\sigma_{h}{ }^{\prime}\right)$ stress and vertical strain $\left(\varepsilon_{v}\right)$ are plotted vs. time. Open arrows = times for unexpected test shut-down. Plot shows that test conditions remained quite constant before and after test shut-down.

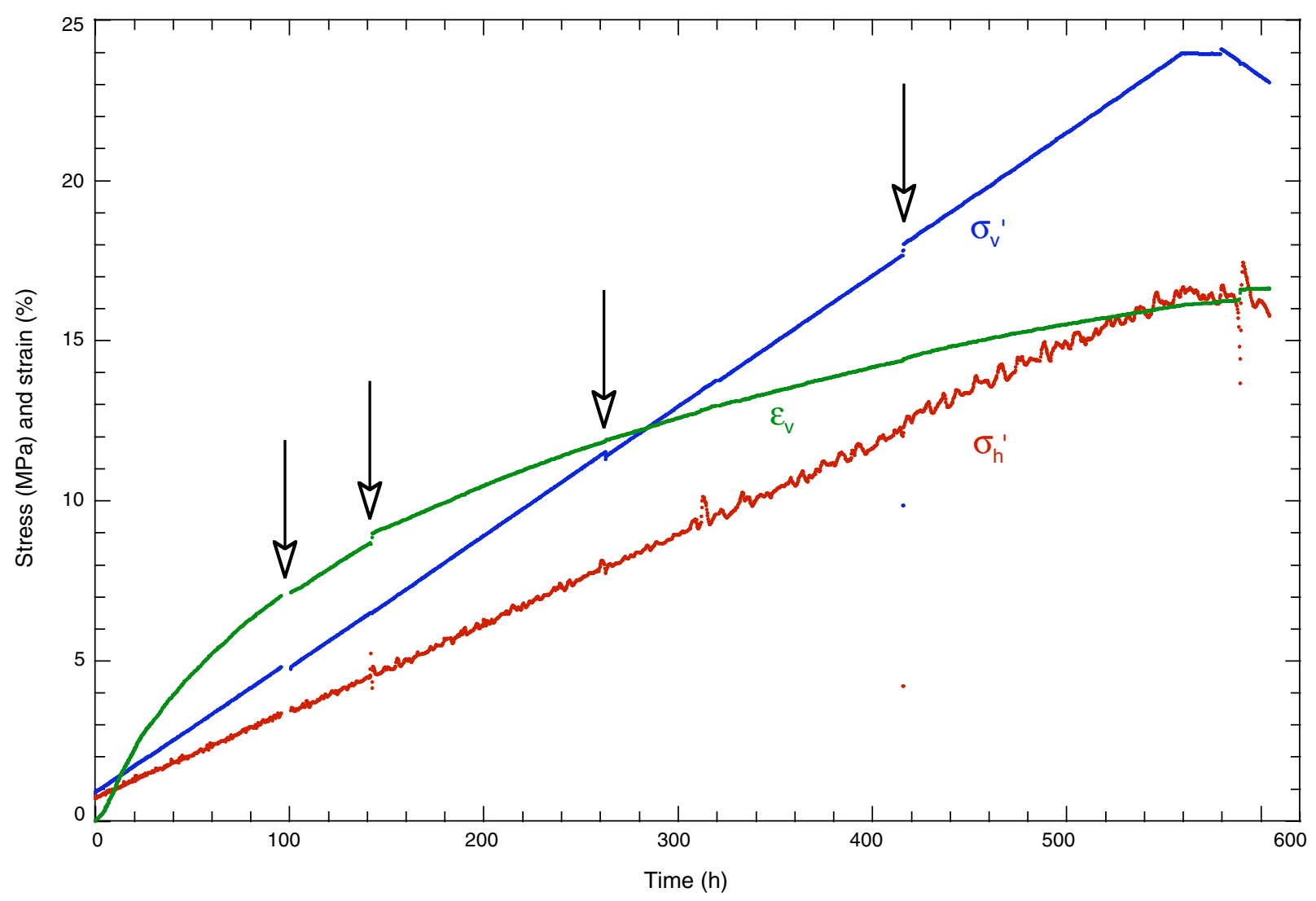


Figure F4. Plots of results for Sample 1320-31-1. A. Effective horizontal stress $\left(\sigma_{\mathrm{h}}{ }^{\prime}\right)$ plotted against effective vertical stress $\left(\sigma_{v}{ }^{\prime}\right)$. Open arrows $=$ times for unexpected test shut-down, solid arrow $=$ effective vertical yield stress $\left(\sigma_{y}{ }^{\prime}\right)$, which is subtle in the stress-stress plots (e.g., insert of A) and more distinct in the strain-stress plot (C). Slope of curve $=$ stress ratio $\left(K_{0}\right.$ in $\mathrm{A} ; \eta_{\mathrm{Ko}}$ in $\left.\mathrm{B}\right)$. Values in italics in $(\mathrm{A})=K_{0}$ values for sections with continuous data collection. (Continued on next two pages.)

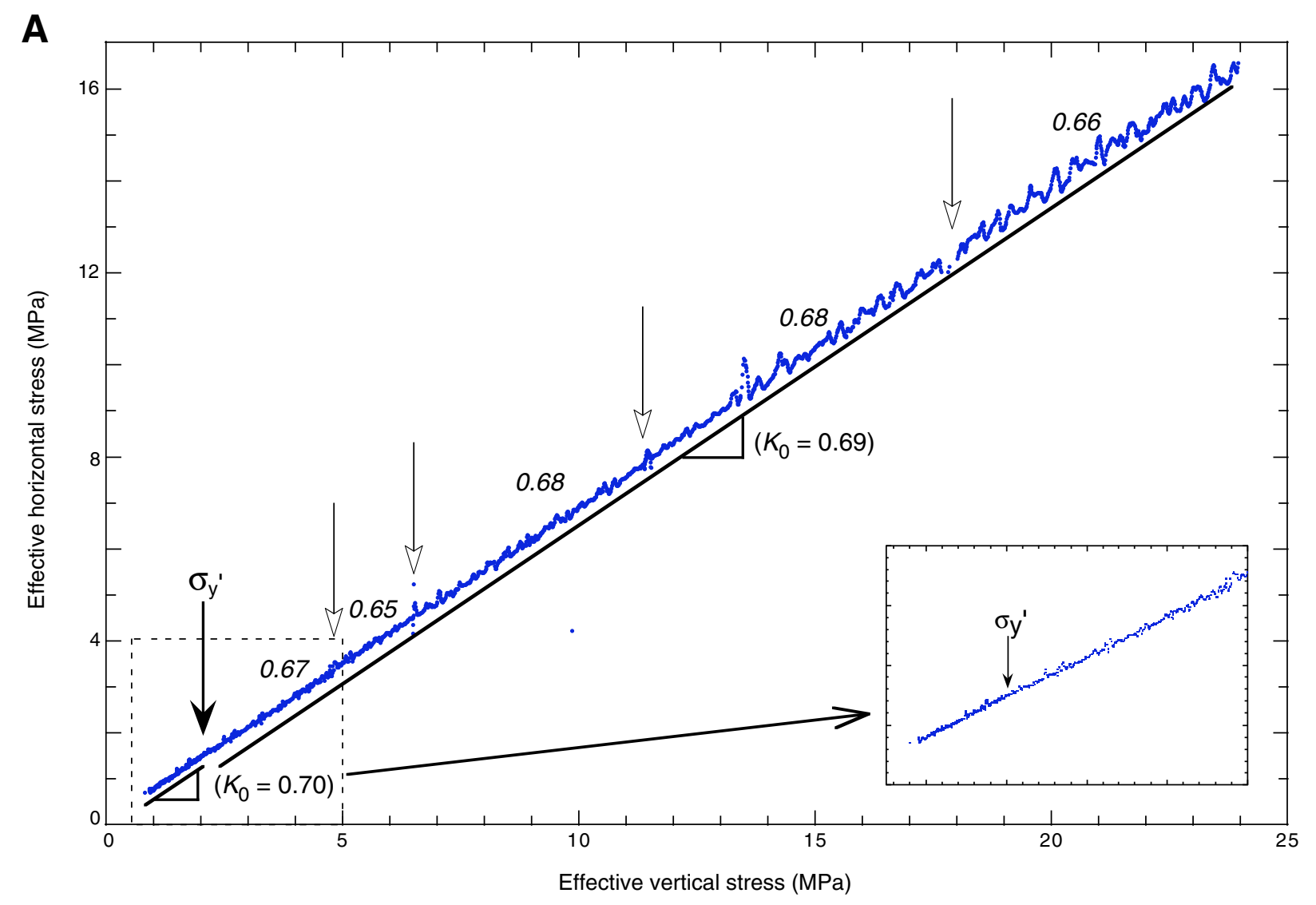


Figure F4 (continued). B. Differential stress $(\Delta \sigma)$ plotted against effective mean stress $\left(\sigma_{\mathrm{m}}{ }^{\prime}\right)$. (Continued on next page.)

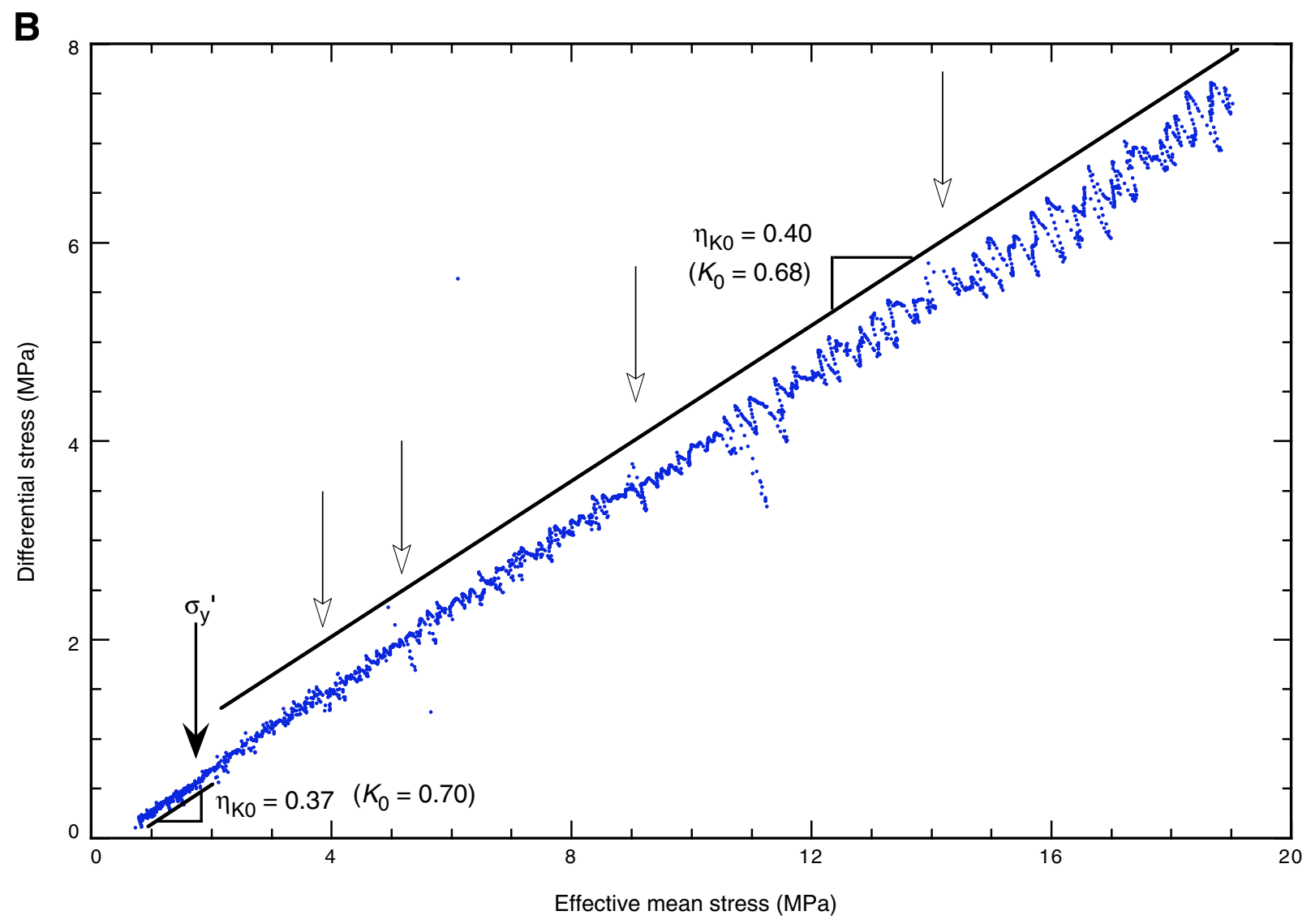


Figure F4 (continued). C. Vertical strain $\left(\varepsilon_{v}\right)$ plotted against effective vertical stress $\left(\sigma_{v}{ }^{\prime}\right)$.

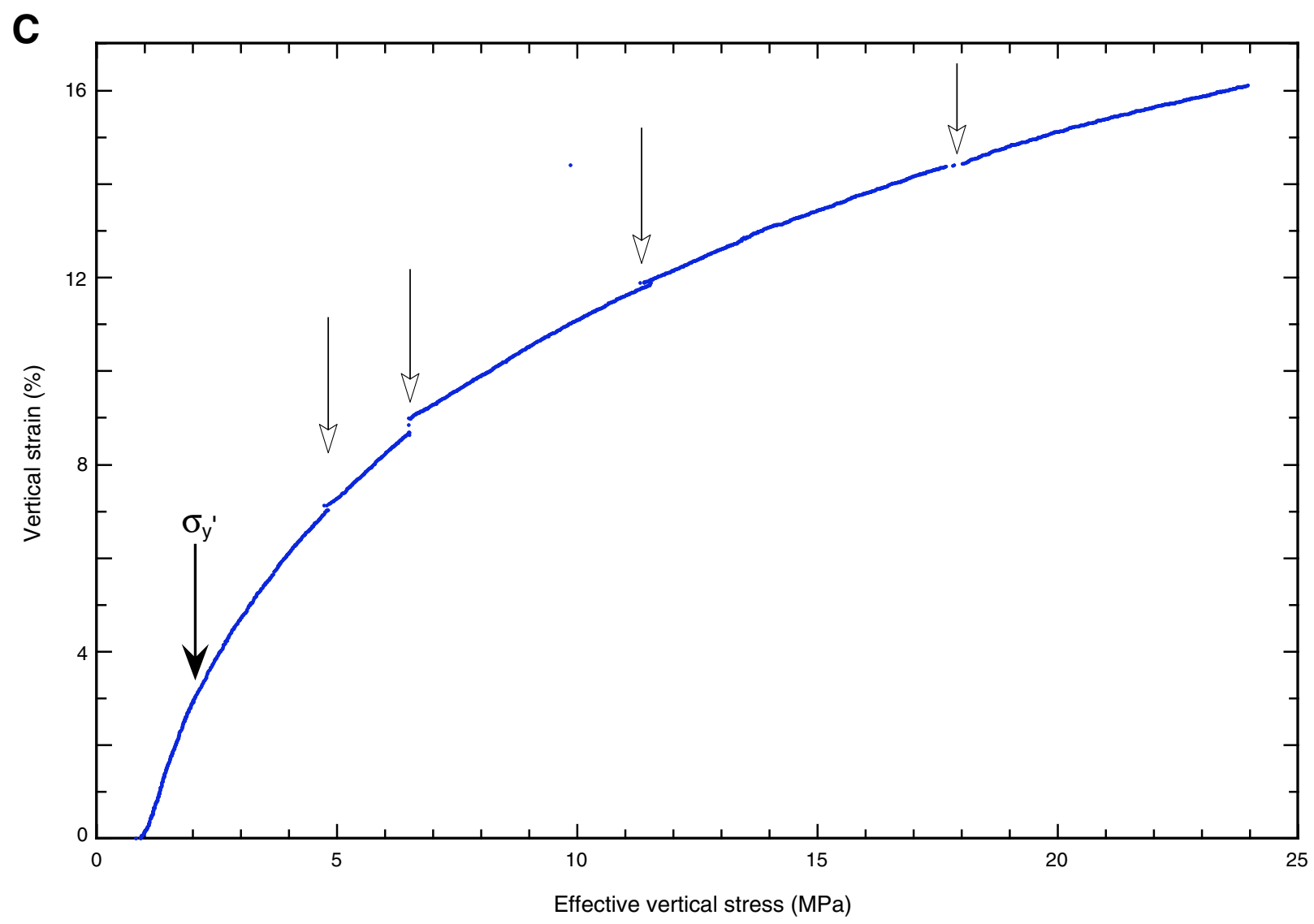


Table T1. Common symbols used in text.

\begin{tabular}{|c|c|}
\hline Symbol & Definition \\
\hline$g$ & Gravitational acceleration, $9.8 \mathrm{~m} / \mathrm{s}^{2}$ \\
\hline$z$ & Burial depth in meters below seafloor (mbsf) \\
\hline$H$ & Depth below sea level, m \\
\hline$L$ & Sample length, $\mathrm{mm}$ \\
\hline$\varepsilon_{\mathrm{v}}$ & Vertical strain in the tests, \% \\
\hline$\varepsilon_{\mathrm{r} 1}$ to $\varepsilon_{\mathrm{r} 4}$ & Horizontal strains in the tests along four directions, $45^{\circ}$ apart, $\%$ \\
\hline$\varepsilon_{\mathrm{vol}}$ & Volumetric strain in the test, \% \\
\hline$K_{0}$ & Stress ratio during uniaxial strain, dimensionless, $K_{0}=\Delta \sigma_{\mathrm{h}}{ }^{\prime} / \Delta \sigma_{\mathrm{v}}{ }^{\prime}=\left(3-\eta_{K_{0}}\right) /\left(3+2 \cdot \eta_{K_{0}}\right)$ \\
\hline$\lambda *$ & Maximum overpressure ratio, dimensionless, $\lambda^{*}=P^{* \max } / \sigma_{\mathrm{vh}}$ \\
\hline$\eta_{\kappa 0}$ & Stress ratio during uniaxial strain, dimensionless, $\eta_{K 0}=\Delta(\Delta \sigma) / \Delta \sigma_{\mathrm{m}}{ }^{\prime}$ \\
\hline$\rho_{\mathrm{g}}$ & Sediment grain density, $\mathrm{g} / \mathrm{cm}^{3}$ \\
\hline$\rho_{\mathrm{w}}$ & Seawater density, $\mathrm{g} / \mathrm{cm}^{3}, \rho_{\mathrm{w}}=1.035 \mathrm{~g} / \mathrm{cm}^{3}$ \\
\hline$\rho_{\mathrm{b}}$ & Sediment bulk density, $\mathrm{g} / \mathrm{cm}^{3}$, total weight/total volume \\
\hline$\eta$ & Sediment porosity, $\%$, volume of pore fluid/total volume, $\eta=\left(\rho_{g}-\rho_{b}\right) /\left(\rho_{g}-\rho_{w}\right) \cdot 100$ \\
\hline$P_{\mathrm{w}}$ & Hydrostatic fluid pressure acting on sediment, $\mathrm{MPa}, P_{\mathrm{w}}=\rho_{\mathrm{w}} \cdot g \cdot H$ \\
\hline$P_{\mathrm{f}}$ & Total pore fluid pressure acting on sediment, MPa \\
\hline$P^{*}$ & Excess pore fluid pressure, $\mathrm{MPa}, P^{*}=P_{\mathrm{f}}-P_{\mathrm{w}}$ \\
\hline$p^{* \max }$ & Maximum pore fluid pressure in excess of hydrostatic water pressure, MPa, $P^{* m a x}=\sigma_{v h^{\prime}}-\sigma_{y}{ }^{\prime}$ \\
\hline$\sigma_{\mathrm{v}}$ & Total vertical stress, $\mathrm{MPa}, \sigma_{\mathrm{v}}=\left(\rho_{\mathrm{b}}-\rho_{\mathrm{w}}\right) \cdot g \cdot z+P_{\mathrm{w}}$ \\
\hline$\sigma_{v}^{\prime}$ & Effective vertical stress, $\mathrm{MPa}, \sigma_{\mathrm{v}}{ }^{\prime}=\sigma_{\mathrm{v}}-P_{\mathrm{f}}=\left(\rho_{\mathrm{b}}-\rho_{\mathrm{w}}\right) \cdot g \cdot z+P^{*}$ \\
\hline$\sigma_{h^{\prime}}$ & Effective horizontal stress, MPa \\
\hline$\sigma_{\mathrm{vh}}{ }^{\prime}$ & In situ effective vertical stress for hydrostatic pore pressure, $\mathrm{MPa}, \sigma_{\mathrm{vh}}{ }^{\prime}=\sigma_{\mathrm{v}}-P_{\mathrm{w}}=\left(\rho_{\mathrm{b}}-\rho_{\mathrm{w}}\right) \cdot g \cdot z$ \\
\hline$\Delta \sigma$ & Differential stress in tests, $\mathrm{MPa}, \Delta \sigma=\sigma_{v}{ }^{\prime}-\sigma_{h}{ }^{\prime}$ \\
\hline$\sigma_{\mathrm{m}}^{\prime}$ & Effective mean stress, $\mathrm{MPa}, \sigma_{\mathrm{m}}{ }^{\prime}=\left(\sigma_{\mathrm{v}}{ }^{\prime}+2 \cdot \sigma_{\mathrm{h}}{ }^{\prime}\right) / 3$ \\
\hline$\sigma_{y}^{\prime}$ & Effective vertical yield stress in tests, MPa \\
\hline
\end{tabular}


Table T2. Raw data from the preconsolidation phase. (See table notes.)

\begin{tabular}{|c|c|c|c|c|c|c|c|c|c|c|c|}
\hline $\begin{array}{c}\text { Time } \\
\text { (h) }\end{array}$ & $\begin{array}{c}\varepsilon_{\mathrm{v}} \\
(\%)\end{array}$ & $\begin{array}{c}\varepsilon_{\mathrm{r} 1} \\
(\%)\end{array}$ & $\begin{array}{c}\varepsilon_{\mathrm{r} 2} \\
(\%)\end{array}$ & $\begin{array}{l}\varepsilon_{\mathrm{r} 3} \\
(\%)\end{array}$ & $\begin{array}{c}\varepsilon_{\mathrm{r} 4} \\
(\%)\end{array}$ & $\begin{array}{l}\varepsilon_{\mathrm{vol}} \\
(\%)\end{array}$ & $\begin{array}{c}\sigma_{\mathrm{v}}{ }^{\prime} \\
(\mathrm{MPa})\end{array}$ & $\begin{array}{c}\sigma_{\mathrm{h}}{ }^{\prime} \\
(\mathrm{MPa})\end{array}$ & $\begin{array}{c}\Delta \sigma \\
(\mathrm{MPa})\end{array}$ & $\begin{array}{c}\sigma_{\mathrm{m}}^{\prime} \\
(\mathrm{MPa})\end{array}$ & $\stackrel{L}{L}$ \\
\hline 0.03 & 0.0000 & 0.0000 & 0.0000 & 0.0000 & 0.0000 & 0.0000 & 0.0000 & 0.0000 & 0.0000 & 0.0000 & 55.2700 \\
\hline 0.47 & 1.7376 & -0.4845 & -0.4001 & -0.6016 & -0.0011 & 0.7621 & 0.7404 & 0.6490 & 0.0914 & 0.6795 & 51.8259 \\
\hline 0.71 & 1.9490 & -0.3696 & -0.2640 & -0.4461 & -0.0013 & 1.2426 & 0.7435 & 0.6512 & 0.0923 & 0.6820 & 51.7347 \\
\hline 0.97 & 2.1305 & -0.2534 & -0.1230 & -0.2676 & 0.0009 & 1.7109 & 0.7439 & 0.6531 & 0.0908 & 0.6834 & 51.6595 \\
\hline 1.21 & 2.2564 & -0.1454 & 0.0039 & -0.1268 & 0.0008 & 2.0826 & 0.7438 & 0.6541 & 0.0898 & 0.6840 & 51.6103 \\
\hline 1.47 & 2.3914 & -0.0327 & 0.1327 & 0.0143 & 0.0013 & 2.4671 & 0.7431 & 0.6557 & 0.0874 & 0.6848 & 51.5634 \\
\hline 1.71 & 2.5225 & 0.0559 & 0.2402 & 0.1248 & 0.0021 & 2.7973 & 0.7446 & 0.6568 & 0.0878 & 0.6860 & 51.5265 \\
\hline 1.97 & 2.6443 & 0.1464 & 0.3391 & 0.2327 & 0.0022 & 3.1115 & 0.7432 & 0.6577 & 0.0855 & 0.6862 & 51.4928 \\
\hline 2.21 & 2.7425 & 0.2257 & 0.4228 & 0.3187 & 0.0032 & 3.3703 & 0.7424 & 0.6588 & 0.0836 & 0.6867 & 51.4669 \\
\hline 2.47 & 2.8171 & 0.3213 & 0.5068 & 0.3972 & -0.0009 & 3.6112 & 0.7450 & 0.6596 & 0.0854 & 0.6881 & 51.4493 \\
\hline 2.71 & 2.8935 & 0.3535 & 0.5583 & 0.4637 & 0.0023 & 3.7838 & 0.7448 & 0.6605 & 0.0843 & 0.6886 & 51.4294 \\
\hline 2.98 & 2.9575 & 0.4231 & 0.6167 & 0.5225 & 0.0019 & 3.9677 & 0.7457 & 0.6617 & 0.0841 & 0.6897 & 51.4120 \\
\hline 3.22 & 3.0109 & 0.4597 & 0.6659 & 0.5737 & 0.0029 & 4.1087 & 0.7472 & 0.6622 & 0.0850 & 0.6905 & 51.3973 \\
\hline 3.48 & 3.0651 & 0.5000 & 0.7251 & 0.6219 & 0.0041 & 4.2573 & 0.7479 & 0.6629 & 0.0851 & 0.6912 & 51.3828 \\
\hline 3.72 & 3.1001 & 0.5361 & 0.7609 & 0.6578 & 0.0044 & 4.3610 & 0.7493 & 0.6634 & 0.0859 & 0.6921 & 51.3725 \\
\hline 3.98 & 3.1385 & 0.5724 & 0.7942 & 0.6954 & 0.0051 & 4.4678 & 0.7494 & 0.6641 & 0.0853 & 0.6925 & 51.3604 \\
\hline 4.22 & 3.1950 & 0.6021 & 0.8235 & 0.7259 & 0.0063 & 4.5810 & 0.7501 & 0.6645 & 0.0856 & 0.6930 & 51.3525 \\
\hline 4.48 & 3.2180 & 0.6276 & 0.8528 & 0.7530 & 0.0061 & 4.6561 & 0.7501 & 0.6645 & 0.0856 & 0.6931 & 51.3445 \\
\hline 4.72 & 3.2371 & 0.6475 & 0.8733 & 0.7733 & 0.0059 & 4.7137 & 0.7506 & 0.6649 & 0.0857 & 0.6935 & 51.3386 \\
\hline 4.98 & 3.2621 & 0.6691 & 0.8981 & 0.7976 & 0.0066 & 4.7836 & 0.7509 & 0.6654 & 0.0855 & 0.6939 & 51.3327 \\
\hline 5.22 & 3.2726 & 0.6864 & 0.9154 & 0.8148 & 0.0071 & 4.8272 & 0.7512 & 0.6657 & 0.0856 & 0.6942 & 51.3271 \\
\hline 5.48 & 3.2874 & 0.7016 & 0.9317 & 0.8340 & 0.0079 & 4.8742 & 0.7512 & 0.6656 & 0.0856 & 0.6942 & 51.3196 \\
\hline 5.72 & 3.3057 & 0.7142 & 0.9443 & 0.8474 & 0.0076 & 4.9168 & 0.7520 & 0.6662 & 0.0858 & 0.6948 & 51.3155 \\
\hline 5.98 & 3.3198 & 0.7282 & 0.9558 & 0.8626 & 0.0080 & 4.9567 & 0.7530 & 0.6667 & 0.0863 & 0.6955 & 51.3115 \\
\hline 6.22 & 3.3269 & 0.7402 & 0.9681 & 0.8726 & 0.0079 & 4.9858 & 0.7535 & 0.6668 & 0.0867 & 0.6957 & 51.3070 \\
\hline 6.48 & 3.3421 & 0.7504 & 0.9764 & 0.8844 & 0.0070 & 5.0200 & 0.7538 & 0.6674 & 0.0864 & 0.6962 & 51.3036 \\
\hline 6.72 & 3.3500 & 0.7559 & 0.9883 & 0.8935 & 0.0079 & 5.0446 & 0.7532 & 0.6670 & 0.0862 & 0.6957 & 51.3001 \\
\hline 6.98 & 3.3576 & 0.7666 & 0.9963 & 0.9021 & 0.0080 & 5.0696 & 0.7536 & 0.6674 & 0.0862 & 0.6962 & 51.2982 \\
\hline 7.22 & 3.3676 & 0.7713 & 1.0036 & 0.9096 & 0.0082 & 5.0919 & 0.7540 & 0.6675 & 0.0865 & 0.6963 & 51.2951 \\
\hline 7.48 & 3.3777 & 0.7803 & 1.0120 & 0.9174 & 0.0083 & 5.1180 & 0.7540 & 0.6677 & 0.0863 & 0.6964 & 51.2934 \\
\hline 7.72 & 3.3820 & 0.7878 & 1.0155 & 0.9229 & 0.0076 & 5.1326 & 0.7539 & 0.6674 & 0.0865 & 0.6962 & 51.2936 \\
\hline 7.98 & 3.3880 & 0.7897 & 1.0210 & 0.9301 & 0.0074 & 5.1479 & 0.7540 & 0.6677 & 0.0864 & 0.6965 & 51.2913 \\
\hline 8.22 & 3.3979 & 0.7942 & 1.0237 & 0.9347 & 0.0075 & 5.1652 & 0.7546 & 0.6682 & 0.0864 & 0.6970 & 51.2902 \\
\hline 8.48 & 3.4007 & 0.7993 & 1.0281 & 0.9407 & 0.0073 & 5.1778 & 0.7552 & 0.6686 & 0.0866 & 0.6974 & 51.2880 \\
\hline 8.72 & 3.4042 & 0.8031 & 1.0341 & 0.9448 & 0.0070 & 5.1901 & 0.7547 & 0.6683 & 0.0864 & 0.6971 & 51.2866 \\
\hline 8.98 & 3.4119 & 0.8094 & 1.0395 & 0.9513 & 0.0074 & 5.2094 & 0.7547 & 0.6680 & 0.0867 & 0.6969 & 51.2848 \\
\hline
\end{tabular}

Notes: Symbols are defined in Table T1. Only a portion of this table appears here. The complete table is available in Microsoft Excel format as PRECONSOL.XLS in STRESS in "Supplementary material." 
Table T3. Raw data from the $K_{0}$ reconsolidation phase. (See table notes.)

\begin{tabular}{|c|c|c|c|c|c|c|c|c|c|c|c|}
\hline $\begin{array}{c}\text { Time } \\
\text { (h) }\end{array}$ & $\begin{array}{c}\varepsilon_{\mathrm{v}} \\
(\%)\end{array}$ & $\begin{array}{c}\varepsilon_{\mathrm{r} 1} \\
(\%)\end{array}$ & $\begin{array}{c}\varepsilon_{\mathrm{r} 2} \\
(\%)\end{array}$ & $\begin{array}{c}\varepsilon_{\mathrm{r} 3} \\
(\%)\end{array}$ & $\begin{array}{c}\varepsilon_{\mathrm{r} 4} \\
(\%)\end{array}$ & $\begin{array}{l}\varepsilon_{\mathrm{vol}} \\
(\%)\end{array}$ & $\begin{array}{c}\sigma_{\mathrm{v}}{ }^{\prime} \\
(\mathrm{MPa})\end{array}$ & $\begin{array}{c}\sigma_{\mathrm{h}}{ }^{\prime} \\
(\mathrm{MPa})\end{array}$ & $\begin{array}{c}\sigma_{\mathrm{m}}^{\prime} \\
(\mathrm{MPa})\end{array}$ & $\begin{array}{c}\Delta \sigma \\
(\mathrm{MPa})\end{array}$ & $\begin{array}{c}L \\
(\mathrm{~mm})\end{array}$ \\
\hline 0.03 & 0.0000 & 0.0000 & 0.0000 & 0.0000 & 0.0000 & 0.0000 & 0.8085 & 0.7019 & 0.7374 & 0.1066 & 51.2200 \\
\hline 0.10 & 0.0085 & 0.0081 & 0.0017 & 0.0002 & -0.0031 & 0.0153 & 0.9120 & 0.7945 & 0.8337 & 0.1175 & 51.2096 \\
\hline 0.17 & 0.0184 & 0.0096 & 0.0033 & 0.0018 & -0.0034 & 0.0283 & 0.9140 & 0.7873 & 0.8295 & 0.1267 & 51.1794 \\
\hline 0.23 & 0.0263 & 0.0108 & 0.0048 & 0.0041 & -0.0030 & 0.0395 & 0.9167 & 0.7732 & 0.8210 & 0.1435 & 51.1745 \\
\hline 0.30 & 0.0345 & 0.0097 & 0.0041 & 0.0034 & -0.0035 & 0.0461 & 0.9176 & 0.7563 & 0.8101 & 0.1613 & 51.1691 \\
\hline 0.37 & 0.0425 & 0.0125 & 0.0023 & 0.0038 & -0.0025 & 0.0550 & 0.9219 & 0.7395 & 0.8003 & 0.1824 & 51.1648 \\
\hline 0.44 & 0.0528 & 0.0104 & -0.0013 & 0.0009 & -0.0023 & 0.0596 & 0.9226 & 0.7214 & 0.7885 & 0.2012 & 51.1590 \\
\hline 0.50 & 0.0587 & 0.0093 & -0.0046 & -0.0059 & -0.0019 & 0.0580 & 0.9232 & 0.7095 & 0.7807 & 0.2137 & 51.1553 \\
\hline 0.57 & 0.0609 & 0.0061 & -0.0082 & -0.0099 & -0.0018 & 0.0530 & 0.9273 & 0.7115 & 0.7834 & 0.2158 & 51.1515 \\
\hline 0.64 & 0.0631 & 0.0074 & -0.0065 & -0.0046 & -0.0021 & 0.0607 & 0.9308 & 0.7212 & 0.7911 & 0.2096 & 51.1515 \\
\hline 0.70 & 0.0641 & 0.0080 & -0.0065 & -0.0036 & -0.0020 & 0.0628 & 0.9338 & 0.7285 & 0.7970 & 0.2052 & 51.1508 \\
\hline 0.77 & 0.0639 & 0.0056 & -0.0085 & -0.0086 & -0.0015 & 0.0563 & 0.9360 & 0.7337 & 0.8011 & 0.2023 & 51.1490 \\
\hline 0.84 & 0.0643 & 0.0041 & -0.0084 & -0.0095 & -0.0015 & 0.0552 & 0.9393 & 0.7422 & 0.8079 & 0.1971 & 51.1488 \\
\hline 0.90 & 0.0663 & 0.0061 & -0.0079 & -0.0082 & -0.0017 & 0.0597 & 0.9420 & 0.7510 & 0.8147 & 0.1910 & 51.1486 \\
\hline 0.97 & 0.0671 & 0.0052 & -0.0069 & -0.0062 & -0.0014 & 0.0619 & 0.9437 & 0.7577 & 0.8197 & 0.1860 & 51.1466 \\
\hline 1.04 & 0.0705 & 0.0083 & -0.0035 & -0.0053 & -0.0016 & 0.0702 & 0.9467 & 0.7663 & 0.8264 & 0.1804 & 51.1455 \\
\hline 1.10 & 0.0745 & 0.0085 & -0.0031 & 0.0009 & -0.0016 & 0.0788 & 0.9493 & 0.7674 & 0.8280 & 0.1819 & 51.1431 \\
\hline 1.17 & 0.0782 & 0.0089 & -0.0042 & -0.0047 & -0.0012 & 0.0784 & 0.9522 & 0.7644 & 0.8270 & 0.1878 & 51.1399 \\
\hline 1.24 & 0.0804 & 0.0074 & -0.0045 & -0.0034 & -0.0010 & 0.0802 & 0.9549 & 0.7664 & 0.8292 & 0.1885 & 51.1384 \\
\hline 1.30 & 0.0799 & 0.0039 & -0.0060 & -0.0091 & -0.0005 & 0.0725 & 0.9579 & 0.7698 & 0.8325 & 0.1880 & 51.1360 \\
\hline 1.37 & 0.0820 & 0.0018 & -0.0041 & -0.0064 & -0.0005 & 0.0762 & 0.9600 & 0.7804 & 0.8402 & 0.1797 & 51.1350 \\
\hline 1.44 & 0.0849 & 0.0056 & -0.0018 & -0.0020 & -0.0009 & 0.0862 & 0.9635 & 0.7888 & 0.8470 & 0.1747 & 51.1337 \\
\hline 1.50 & 0.0914 & 0.0101 & 0.0004 & -0.0005 & -0.0013 & 0.0982 & 0.9656 & 0.7840 & 0.8445 & 0.1816 & 51.1317 \\
\hline 1.57 & 0.0945 & 0.0079 & -0.0024 & -0.0022 & -0.0008 & 0.0968 & 0.9686 & 0.7754 & 0.8398 & 0.1932 & 51.1287 \\
\hline 1.64 & 0.0960 & 0.0005 & -0.0041 & -0.0049 & -0.0005 & 0.0905 & 0.9703 & 0.7732 & 0.8389 & 0.1971 & 51.1259 \\
\hline 1.70 & 0.1020 & 0.0076 & -0.0022 & -0.0038 & -0.0009 & 0.1032 & 0.9725 & 0.7768 & 0.8420 & 0.1957 & 51.1241 \\
\hline 1.77 & 0.1052 & 0.0080 & -0.0017 & -0.0019 & -0.0010 & 0.1082 & 0.9762 & 0.7747 & 0.8419 & 0.2015 & 51.1216 \\
\hline 1.84 & 0.1114 & 0.0058 & -0.0015 & -0.0042 & -0.0010 & 0.1115 & 0.9791 & 0.7705 & 0.8400 & 0.2086 & 51.1185 \\
\hline 1.90 & 0.1191 & 0.0090 & -0.0023 & 0.0014 & -0.0015 & 0.1247 & 0.9805 & 0.7685 & 0.8392 & 0.2120 & 51.1160 \\
\hline 1.97 & 0.1252 & 0.0092 & -0.0033 & -0.0044 & -0.0014 & 0.1263 & 0.9838 & 0.7625 & 0.8363 & 0.2213 & 51.1128 \\
\hline 2.04 & 0.1329 & 0.0094 & -0.0037 & -0.0040 & -0.0018 & 0.1342 & 0.9861 & 0.7594 & 0.8349 & 0.2268 & 51.1074 \\
\hline 2.10 & 0.1396 & 0.0096 & -0.0045 & -0.0015 & -0.0021 & 0.1421 & 0.9881 & 0.7565 & 0.8337 & 0.2316 & 51.1038 \\
\hline
\end{tabular}

Notes: Symbols are defined in Table T1. Only a portion of this table appears here. The complete table is available in Microsoft Excel format as RECONSOL.XLS in STRESS in "Supplementary material." 